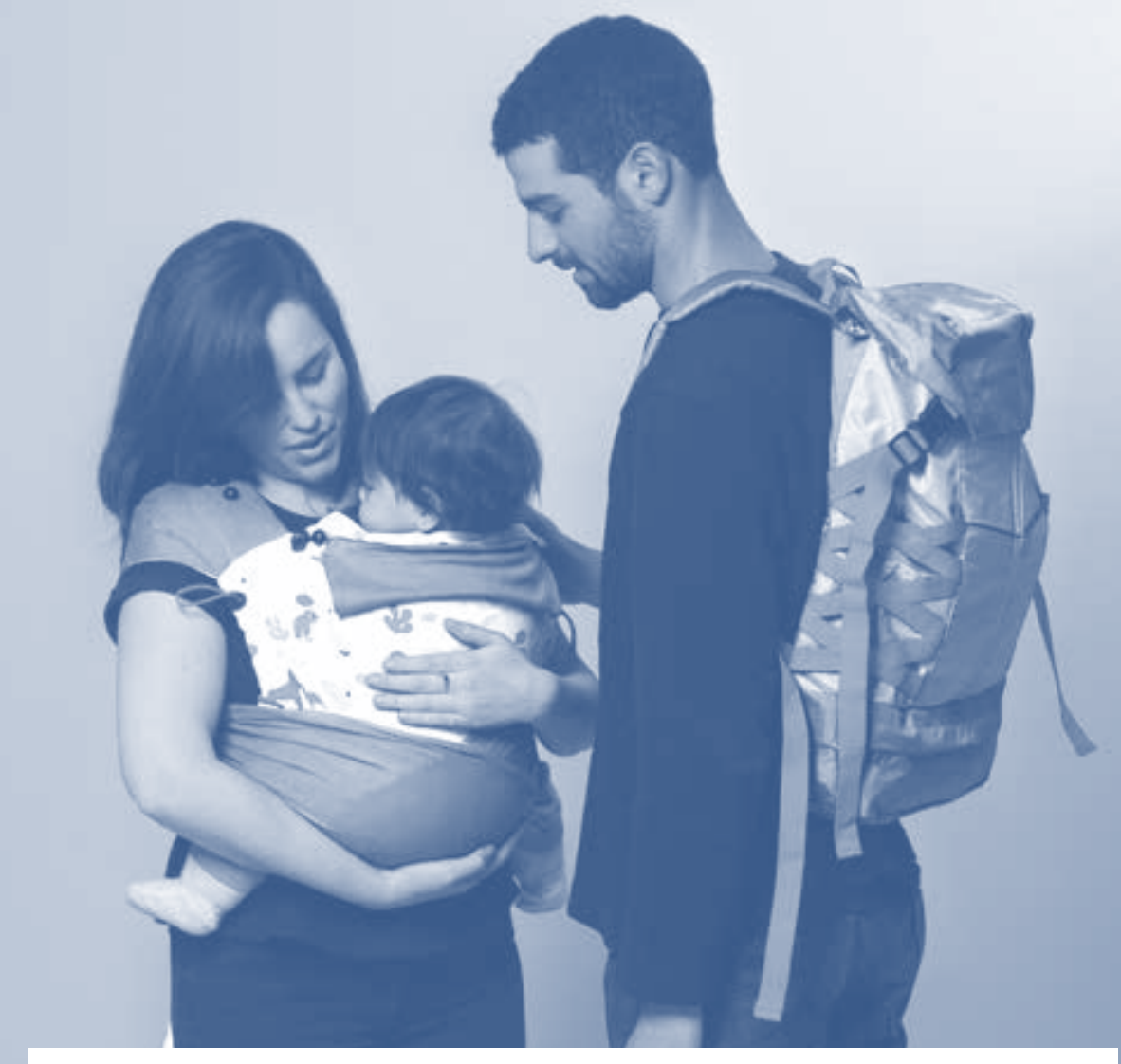

\title{
$\stackrel{\circ}{\circ}$ Rediseño del sistema textil PARN: \\ Pertenencia y equidad desde la primera infancia
} DISEÑA 12 | ENERO 2018 | ISSN: 07188447 | PROVECTO

\section{Redesign of the PARN textile system: Belonging and equity from early childhoode}

DISEÑA 12 I JANUARY 2018 I ISSN: 0718 8447 I PROJECT
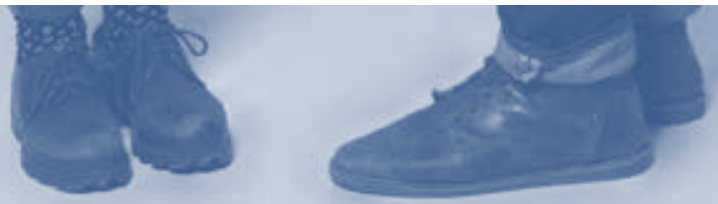

Figura 1: Mochila y portabebé. Fotografía: Omar Faúndez.

Figure 1: Backpack and baby carrier. Photography: Omar Faúndez. 
Camila Ríos Erazo Docente de la Escuela de Diseño Pontificia Universidad Católica de Chile. Se interesa por las construcciones textiles, la tecnología textil y el diseño de productos. Lidera el espacio de Investigación del Fablab Santiago Open Textiles, instancia que busca abrir nuevas interrogantes en el ámbito textil a partir de la producción y la funcionalidad.
Desde 2009, el Estado chileno entrega un ajuar a las familias que reciben a sus hijos en los hospitales del sistema público. Este ajuar incluye numerosos elementos, desde una cuna corral hasta material educativo, pasando por un porta bebé y una mochila. Más de 160 mil niños reciben este beneficio cada año. La iniciativa no sólo disminuye los gastos en que incurren las familias con la llegada de un nuevo hijo, sino que también fomenta el pleno desarrollo emocional de los niños y promueve el desarrollo transversal de sus derechos. Este artículo describe el reciente proceso de rediseño de los elementos incluidos en el ajuar, cuyo propósito fue promover el sentido de pertenencia y la equidad. Se detallan el contexto en que se inserta el proyecto, los antecedentes, los referentes y el proceso de levantamiento de información que informa la propuesta.

Since 2009, the Chilean State has provided a baby box to the families whose children are born in public hospitals. This baby box contains numerous items, from a playpen cradle to educational material, and also includes a baby carrier and a backpack. More than 160,000 children receive this benefit every year. The initiative not only reduces the expenses incurred by families who welcome a new child, but also promotes the full emotional development of children as well as the transversal development of their rights. This article describes the recent process of redesigning the elements included in the baby box, whose purpose was to promote a sense of belonging and equity. The context in which the project is inserted, its background, the referents and the process of gathering information for the proposal are also detailed. 


\section{CONTEXTO}

Este proyecto nace al alero del sistema de protección a la infancia Chile Crece Contigo, cuyo objetivo es promover el desarrollo de los niños en la primera infancia, especialmente de aquellos en situación vulnerable. Esto se consigue mediante la aplicación de una serie de intervenciones y servicios sociales de apoyo psicosocial, entre los que destaca el Programa de Apoyo al Recién Nacido (PARN). Creado en 2009 , el PARN

Brinda apoyo a las familias para asegurar que todos los niños y niñas cuenten con las condiciones óptimas de atención y cuidado en la primera etapa de su desarrollo. Este apoyo consiste en un set de implementos básicos para el recién nacido y en educación para las familias. A través de este set y la educación, se fomenta el cuidado y atención de calidad al recién nacido, la seguridad y protección infantil, la lactancia exclusiva hasta los seis meses, un vínculo de apego entre el recién nacido y su padre, madre o cuidadora y la equidad en el acceso a información sobre cuidados y crianza temprana (Chile Crece Contigo, 2010, p. 45).

\section{CONTEXT}

This project was born under the umbrella of the Chile Crece Contigo ("Chile Grows with You") child protection system, whose objective is to promote the development of children in their early childhood, especially those in vulnerable situations. This is achieved through the application of a series of interventions and social services of psychosocial support, amongst which the Newborn Support Program, PARN (Programa de Apoyo al Recién Nacido) stands out. Created in 2009, the PARN:

Provides support to families to ensure that all children have the optimal conditions of care and attention in the first stage of their development. This support consists of a set of basic implements for the newborn and education for their families. Through this kit and education, quality care and attention for the newborn are promoted, as well as child safety and protection, exclusive breastfeeding for six months, a bond between the newborn and their father, mother or caregiver and equity in access to information on early care and upbringing (Chile Crece Contigo, 2010, p. 45).
Tanto la parte educativa como el set de implementos básicos están dirigidos a «apoyar a las familias de todos los niños y niñas nacidos vivos (as) en los hospitales del Sistema Público de Salud», beneficiando a más de 160.000 niños (Chile Crece Contigo, 2010, p. 45). Estos implementos básicos consisten en un ajuar compuesto por tres sets: una cuna corral equipada, un set de cuidados básicos y estimulación, y un set de apego y vestuario.

Según el último estudio de satisfacción de usuarios del PARN (Datavoz, 2014), que incluyó la realización de más de mil entrevistas, el 59 por ciento de los usuarios pertenece al segmento socioeconómico E, es decir, se trata de familias cuyo ingreso promedio mensual alcanza los 158.000 pesos por hogar (Emol, 2016). Un 50 por ciento de los usuarios completó la educación media (Datavoz, 2014). Dadas estas condiciones, el ajuar es un regalo apreciado. No sólo disminuye los gastos en que incurren las familias al momento de enfrentar la llegada de un nuevo hijo, sino que también promueve el desarrollo transversal de los derechos del niño, fomentando su pleno desarro-

Both the educational part and the set of basic implements are aimed at "supporting the families of all children born in the hospitals of the Public Health System", benefiting more than 160,000 children (Chile Crece Contigo, 2010, p. 45). These basic items are part of a baby box that includes three sets: a playpen cradle, a set for basic care and stimulation, and a set for attachment and clothing.

According to the latest study of user satisfaction of the PARN (Datavoz, 2014), which included more than one thousand interviews, 59 percent of the users belong to the socioeconomic segment $\mathrm{E}$, that is, families whose average monthly income reaches 158,000 Chilean Pesos (USD 250) per household (Emol, 2016). Half of the users completed their secondary education (Datavoz, 2014). Considering these conditions, the baby box is a valued gift. Not only does it reduce the expenses incurred by families when facing the arrival of a new child, but it also promotes the development of children's rights, encouraging their full development from an economic and emotional standpoint. 
llo desde un ámbito económico y emocional.

\section{ANTECEDENTES}

En 2014, considerando la relevancia y el alcance del programa, Chile Crece Contigo, el Ministerio de Desarrollo Social y la Escuela de Diseño de la Pontificia Universidad Católica de Chile firmaron un convenio que contempló el rediseño del packaging de los implementos básicos para el recién nacido. La idea fue promover el segundo uso del embalaje y mejorar el transporte desde los establecimientos de salud hacia los lugares de residencia de los beneficiarios. Cabe hacer notar que este convenio surgió a partir de un taller de verano con estudiantes de la UC, liderado por los académicos de la carrera de Diseño Patricia Manns, Alberto González, Iván Caro, Patricia de los Ríos y Camila Ríos.

La situación inicial, que debía ser rediseñada, constaba de cuatro empaques, uno para cada uno de los paquetes: el de apego y vestuario, el de cuidados básicos y estimulación, el de la cuna corral equipada y el del colchón. Evidentemente, al salir del centro de salud, la madre y su acompañante no

\section{BACKGROUND}

In 2014, considering the relevance and scope of the program Chile Crece Contigo, the Ministry of Social Development and the uc Design School signed an agreement that included the redesign of the packaging of these basic implements for the newborn. The idea was to promote the second use of packaging and improve transport from health facilities to the residence of the beneficiaries. It should be noted that this agreement emerged from a summer workshop with uc students, led by the academics of the Design career Patricia Manns, Alberto Conzalez, Iván Caro, Patricia de los Ríos and Camila Ríos.

The initial state, which had to be redesigned, consisted of four packages, one for each of the sets: attachment and clothing, basic care and stimulation, playpen cradle and mattress. Obviously, when leaving the health care center, the mother and her companion could not cope with carrying all of these elements. Thus, it became essential to reduce the amount of packaging to facilitate their transport. daban abasto para cargar todos estos elementos. Así, se tornaba fundamental reducir la cantidad de empaques para facilitar el traslado. Luego de un análisis cualitativo y otro cuantitativo, y del análisis de los atributos que debía recoger la propuesta, los elementos que componen el PARN fueron reagrupados en tres nuevos embalajes, organizados por su uso y funcionalidad. A saber:

Set buen dormir: cuna corral armable, funda, juego de sábanas, frazada, colcha y móvil de estimulación. Su nuevo embalaje consiste en una caja baúl que promueve el segundo uso como espacio para guardar diversos objetos del bebé o la familia.

Set bienestar, apego y estimulación: cojín de lactancia, porta bebé tipo Mei-tai, material educativo, vestuario, mudador plástico plegable, mochila para artículos de bebé, libros, toalla y artículos de aseo. El nuevo packaging consiste en un bolso textil ligero que se transforma en un organizador vertical para los distintos objetos del recién nacido.

Set de complementos para dormir y estimulación: colchón y alfombra de goma eva. El nuevo packaging consiste en una bolsa plástica ligera con

After a qualitative and a quantitative analysis, and an analysis of the attributes that the proposal had to collect, the elements that make up the PARN were grouped into three new packages, organized by their use and functionality, namely:

"Cood sleep" set: DIY playpen cradle, cover, set of sheets, blanket, bedspread and stimulation mobile. Its new packaging consists of a box-chest that promotes a second use as a storage place for various baby-related items, or for any items the family deems convenient.

"Wellness, Attachment and Stimulation" set: lactation cushion, Mei Tai baby carrier, educational material, wardrobe, folding plastic diaper changer, backpack for baby items, books, towel and toiletries. The new packaging consists of a lightweight textile bag that becomes a vertical organizer for the different items of the newborn.

A set of accessories for sleeping and stimulation: a mattress and an EVA rubber mat. The new packaging consists of a light plastic bag with a handle. 
un asa.

La solución propuesta logró disminuir a tres los embalajes, cumpliendo con los requisitos de traslado y reutilización. Una vez concluido el proyecto, y analizados los datos del último estudio de satisfacción de usuarios del PARN (Datavoz, 2014), surgieron distintas oportunidades de diseño que apuntaban a mejorar el sistema textil del ajuar, es decir, el portabebé y la mochila. En este contexto, Chile Crece Contigo solicitó desarrollar el rediseño de todos estos productos. Dada la envergadura del proyecto, quien escribe invitó a trabajar a las estudiantes de Diseño uc Ana Schacht y Lourdes Sotomayor.

\section{REFERENTES}

Dos iniciativas finlandesas constituyen un importante marco referencial. Desde hace 79 años, el Estado finlandés entrega a las familias un ajuar que consta de una caja/cuna, ropa y una serie de implementos básicos de higiene y uso diario. Estos implementos han ido evolucionando a lo largo de los años en función de las necesidades de las perso-

The proposed solution managed to reduce the packaging to three items, complying with the transport and reuse requirements. Once the project was concluded, and the data from the last user satisfaction study of the PARN (Datavoz, 2014) was analyzed, different design opportunities emerged that aimed to improve the textile system of the baby box, that is, the baby carrier and the backpack. In this context, Chile Crece Contigo requested the redesign of all of these products. Considering the size of the project, the author invited two students from Uc Design School, Ana Schacht and Lourdes Sotomayor, to assist.

\section{REFERENCES}

Two Finnish initiatives constitute an important framework of reference. For 79 years, the Finnish State has provided families with a baby box consisting of a box/cradle, clothes and a series of basic hygiene and daily use implements. These implements have evolved over the years according to the needs nas y sus contextos. Así, inicialmente se entregaban textiles para que las madres confeccionaran la ropa del bebé. Actualmente, respondiendo a las costumbres de las familias, se entrega ropa ya confeccionada. Del análisis de este referente se desprende que cada elemento debe responder a los hábitos de las familias y al contexto local. En este sentido, lo esencial es escuchar y diseñar de manera colaborativa para incrementar el uso y el impacto del proyecto.

El segundo referente, que también tiene su origen en Finlandia, es la compañía de textiles y accesorios Marimekko, fundada en 1951. Marimekko se caracteriza por diseños alegres, atemporales, distintivos y funcionales. Sus diseños incluyen patrones conformados por figuras geométricas con bordes perfilados, con colores lisos y contrastantes. Marimekko fabrica productos de alta calidad, con diseños que no hacen distinción de género y que juegan sutilmente con una imaginería infantil. Estos conceptos fueron relevantes al momento de acoger ciertos comentarios de los usuarios, quienes mencionaban el sentimiento de ridiculez que experimentaban al utilizar productos que están diseñados para

of people and their contexts. Thus, in the beginning, textiles were delivered for mothers to make baby clothes. Currently, and responding to family customs, clothing is delivered ready to wear. From the analysis of this reference, it became clear that each element must respond to the habits of the families and the local context. In this sense, the most important thing is to listen and design collaboratively to increase the use and impact of the project.

The second reference, which also originates in Finland, is the Marimekko textile and accessories company, founded in 1951. Marimekko is characterized by cheerful, timeless, distinctive and functional designs. Their designs include patterns formed by geometric figures with sharp edges, with contrasting colors. Marimekko manufactures high quality products with designs that don't make a distinction of gender and that play subtly with a children's imagery. These concepts were relevant when accepting certain comments from users, who mentioned the sense of ridicule they experienced when using products that are designed 
niños, pero que en realidad son usados por adultos.

Otro elemento clave fue el concepto de "apego", un tipo especial de vínculo afectivo que otorga seguridad y protección (Lecannelier, 2009). Este concepto es definido como «una relación que es duradera en el tiempo, suele ser estable, relativamente consistente, y es permanente durante la mayor parte de la vida de una persona» (Lecannelier, sin año). Dicho concepto fue considerado un eje central al momento de rediseñar el porta bebé, ya que, entre todos los productos del ajuar, es el que cumple más cabalmente con el objetivo de generar el vínculo. De hecho, se detectó que una baja satisfacción respecto del porta bebé, y por consiguiente su escaso uso, podría perjudicar directamente el desarrollo psicoemocional y físico del recién nacido. «El apego no es un momento específico, sino un proceso que se va construyendo día a día en todos los momentos en que la guagua siente y/o expresa algún malestar» (Saavedra Norambuena \& Chile Crece Contigo, 2015, pág. 33). Por este motivo, el nuevo porta bebé se propone, sobre todo, aumentar el porcentaje de uso para que sea utilizado desde el nacimiento.

for children, but that are actually used by adults.

Another key element was the concept of 'attachment', a special type of affective bond that provides security and protection (Lecannelier, 2009). This concept is defined as "a relationship that is durable over time, that is usually stable, relatively consistent, and permanent during most of a person's life" (Lecannelier, no date). This concept was considered a central axis when redesigning the baby carrier since, amongst all the products of the baby box, it is the one that complies more fully with the objective of generating the bond. In fact, it was detected that a low satisfaction with the baby carrier, and therefore its limited use, could directly harm the psycho-emotional and physical development of the newborn. "Attachment is not a specific moment, but a process that is built every day at all times when the baby feels and/or expresses some discomfort" (Saavedra Norambuena \& Chile Crece Contigo, 2015, p. 33). For this reason, the new baby carrier aims, above all, to increase the percentage of use from birth.

\section{LEVANTAMIENTO DE INFORMACIÓN PARA}

\section{EL PROYECTO}

El último estudio de satisfacción de usuarias PARN (Datavoz, 2014) revela que, mientras el 86,3 por ciento de los beneficiarios usa la mochila, sólo el 53 por ciento usa el porta bebé. Asimismo, el porcentaje de satisfacción de la mochila alcanza un 84,6 por ciento y el del porta bebé sólo llega a un 66,8 por ciento. Desde este último estudio no se había obtenido retroalimentación respecto del uso y satisfacción de los productos. Tampoco se había establecido un diálogo que dejara entrever las necesidades del niño y la madre. Establecer este diálogo sería un importante paso y ayudaría al rediseño del PARN desde una visión colaborativa.

Para comenzar el estudio de campo se identificaron los medios por los cuales las madres del segmento atendido hablan de maternidad. La búsqueda se situó en medios formales e informales. Se consideró interesante la expresividad manifestada en redes sociales, donde personas se expresan sin reserva y de manera casual. Así, se reconocieron distintos grupos en Facebook donde las madres se

\section{SURVEY OF INFORMATION FOR THE PROJECT}

The last study of satisfaction of PARN users (Datavoz, 2014) reveals that, while 86.3 percent of the beneficiaries use the backpack, only 53 percent use the baby carrier. Similarly, the percentage of satisfaction of the backpack reaches 84.6 percent, whilst that of the baby carrier only reaches 66.8 percent. Since this last study, no feedback had been obtained regarding the use and satisfaction of the products. Nor had a dialogue been established that would allow us to glimpse the needs of the child and the mother. Establishing this dialogue would be an important step and would help the redesign of the PARN from a collaborative dynamic.

In order to begin the field study, the means by which the mothers of the aforementioned segment talk about motherhood were identified. The search was carried out in formal and informal media. The amount of communication manifested in social networks was considered of interest, as people express themselves without reservation and very 
comunican constantemente en búsqueda de apoyo y aprobación, o simplemente para compartir sus experiencias. En varios de ellos se generan debates respecto al apego, la lactancia y el porteo, entre otros temas. Los grupos donde se genera mayor movimiento fueron "Ajuar Chile" y "Mei tai adictas", los cuales tienen 23.000 y 36.000 miembros respectivamente. Además, Chile Crece Contigo cuenta con una página de Facebook con 106.000 miembros, utilizada para difundir programas, educar a los usuarios y responder consultas breves. Para los miembros, esta página constituye una red de apoyo. Estos medios fueron fundamentales por dos motivos: el alcance y la sinceridad con que se expresan los usuarios.

También se realizó una consulta abierta en línea que permitió actualizar el informe de satisfacción de 2014. Se mantuvieron las preguntas de la encuesta anterior para tener parámetros de comparación y se agregaron preguntas relevantes para el rediseño de los productos. A través de Facebook, esta consulta generó cerca de 500 respuestas. Aunque la encuesta arrojó un alto nivel de satisfacción

casually. Thus, different groups were recognized on Facebook, where mothers communicate constantly in search of support and approval, or simply to share their experiences. In several of these groups, debates are generated regarding attachment, breastfeeding and baby-carrying, among other topics. The groups that generate the most movement were 'Ajuar Chile' ('Baby box Chile') and 'Mei tai adictas' ('Mei Tai Addicts'), which have 23,000 and 36,000 members respectively. In addition, Chile Crece Contigo has a Facebook page with 106,000 members, which is used to disseminate programs, educate users and answer brief questions. For members, this page constitutes a support network. These groups were fundamental for two reasons: their scope and the sincerity with which the users express themselves.

An open online consultation was also carried out, which made it possible to update the 2014 satisfaction report. The questions of the previous survey were used in order to have comparison parameters, and relevant questions were added for the redesign respecto de la mochila y el porta bebé, se quiso ampliar la información con respuestas más libres. Era importante recibir datos cualitativos y emocionales respecto de lo que significa recibir los productos que se debían rediseñar. Por lo tanto, en conjunto con Chile Crece Contigo se difundieron preguntas directas y abiertas a través de su página oficial de Facebook. Las preguntas fueron: "¿qué opinan del Mei tai?”, “¿les gusta?”, “¿por qué?”. Las preguntas sobre la mochila fueron equivalentes. En ambos casos, el alcance rondó las 28.000 personas, de las cuales más de 500 respondieron extensamente.

Así comenzaron a manifestarse algunas inquietudes de los usuarios. No sólo sentían vergüenza al usar la mochila porque consideraban que no tenía una apariencia adecuada para un adulto, como ya se ha dicho, sino que además cuestionaban la funcionalidad y la calidad. En cuanto al porta bebé, los padres que no lo usaban señalaron que no comprendían la usabilidad, y que consideraban que no interactuaba bien con personas con sobrepeso o de baja estatura. Junto con ello, no podían usarlo con bebés recién nacidos.

of the products. Through Facebook, this query generated approximately 500 responses. Although the survey showed a high level of satisfaction with regard to the backpack and the baby carrier, we wanted to expand the information with freer answers. It was important to receive qualitative and emotional data regarding what it means to receive the products that needed to be redesigned. Therefore, in conjunction with Chile Crece Contigo, direct and open questions were disseminated through its official Facebook page. The questions were: "What do you think of the Mei Tai?”, “Do you like it?", “Why?”. Questions about the backpack were equivalent. In both cases, the scope was close to 28,000 people, of which more than 500 responded extensively.

This is how some concerns from the users began to manifest themselves. Not only did they feel embarrassed when using the backpack because they considered that it did not look suitable for an adult, as it has already been said, but they also questioned its functionality and quality. As for the baby carrier, 
Figura 2: Vestuario y cojín de lactancia. Fotografía: Omar Faúndez.

Figura 3: Packaging desplegado como organizador del set

"Bienestar, apego y estimulación". Fotografía: Omar Faúndez.

Figura 4: Set de implementos rediseñados. Mar, Bosque, montaña y desierto.

Fotografías: Omar Faúndez.

Figure 2: Wardrobe and breastfeeding pillow.

Photography: Omar Faúndez.

Figure 3 : Packaging displayed as organizer, from the 'Wellbeing, Attachment and Stimulation' set. Photography: Omar Faúndez.

Figure 4: Set of redesigned implements. Sea, Forest, Mountain and Desert. Photography: Omar Faúndez.

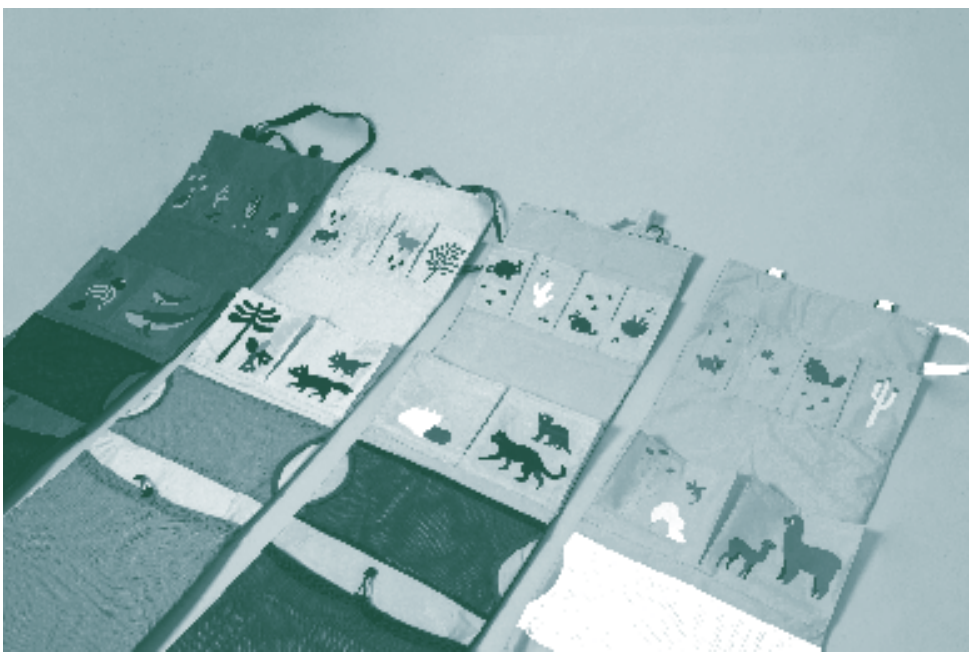


Las respuestas se clasificaron en aquellas que rescataban aspectos positivos y las que enfatizaban aspectos negativos. En general, las respuestas resaltaron la importancia de la colaboración de los usuarios y la influencia del entorno. En este proceso se consideró importante incorporar al equipo a una usuaria del PARN, quien además es asesora de porteo. Esta incorporación permitió obtener información en tres niveles. En primer lugar, fue posible realizar una entrevista en profundidad sobre el uso del porta bebé. En segundo término, se obtuvo una visión crítica y práctica de los aspectos mal evaluados. Finalmente, por su constate contacto con otros usuarios, la asesora de porteo se convirtió en una fuente de retroalimentación directa sobre los eventuales cambios a realizar.

La información recogida se clasificó en necesidades funcionales y necesidades emocionales. Cada necesidad funcional fue corroborada por especialistas, considerando además la visión y misión que los ministerios implicados promueven a través de sus programas. Por otro lado, las necesidades emocionales fueron esquematizadas mediante

the parents who did not use it said that they did not understand its usability, and that they considered that it did not interact well with people who were overweight or of a short stature. Additionally, they could not use it with newborn babies.

The answers were classified into those that highlighted positive aspects and those that emphasized negative aspects. In general, the responses highlighted the importance of user collaboration and the influence of the environment. In this process, it was considered important to incorporate a user of the PARN into the team, who is also a baby carrying consultant. This allowed obtaining information on three levels: Firstly, it was possible to carry out an in-depth interview on the use of the baby carrier; secondly, a critical and practical view of the poorly evaluated aspects was obtained; and finally, because of her regular contact with other users, the baby carrying consultant became a source of direct feedback on the possible changes to be made.

The information collected was then classified distintos conceptos que fueron la columna vertebral del proyecto. Respecto a las necesidades funcionales, en el caso de la mochila se consideró esencial la seguridad y la comodidad, así como que los compartimientos fuesen adecuados para los implementos del niño y de fácil acceso. En cuanto al porta bebé, se consideraron ciertos requerimientos propios de la salud del bebé, así como otros que respondían a la interacción con el portador. Como el propósito era promover el apego desde el momento del nacimiento, fue necesario considerar la correcta postura de la espalda, las piernas y la cabeza del bebé. En cuanto a la interacción del portador, fue prioritaria la comodidad y liviandad del peso en la cadera y los hombros, así como también que ponerse el porta bebé fuese fácil y rápido.

\section{DESCRIPCIÓN DE LA PROPUESTA}

El PAR N llega a todo Chile. Apela a trascender en el tiempo y transmitir pertenencia y equidad. Por este motivo, las formas, los materiales, la gama cromática y las gráficas apelan a la atemporalidad, la pertenencia local y la honestidad. Así, la propuesta

into functional needs and emotional needs. Each functional need was corroborated by specialists, considering the vision and mission that the ministries involved promote through their programs. On the other hand, the emotional needs were outlined through different concepts that were the backbone of the project. Regarding the functional needs, in the case of the backpack, its safety and comfort were considered essential, as well as that the compartments be suitable for the child's items and ease of access. As for the baby carrier, certain requirements related to the baby's health were considered, as well as others that responded to the interaction with the carrier. Since the purpose was to promote attachment from the moment of birth, it was necessary to consider the correct posture of the baby's back, legs and head. As for the carrier's interaction, comfort and lightness of the weight on the hip and shoulders were a priority, as well as the ease and quickness of the process of putting on the baby carrier. 
se cohesiona a través de la reinterpretación gráfica de distintos hábitats: desierto, mar, montaña y bosque. En cada hábitat se ilustró la flora y la fauna característica de la zona. En el caso del mar, se utilizaron imágenes del pingüino de Humboldt, el lobo de mar, la ballena azul y la ballena jorobada. En el caso del bosque se recurrió al pudú, el zorro culpeo, la araucaria, el piñón y el copihue. La montaña fue representada con el puma, la vizcacha de montaña y la yareta. Finalmente, el cactus, la alpaca, la chinchilla y la lagartija caracterizaron al desierto.

\section{PROCESO DE ITERACIÓN}

Durante esta etapa las necesidades funcionales y emocionales se acoplaron en una sola propuesta, que fue evaluada a través de tres sub fases:

1. Reuniones grupales con especialistas: Se corroboró el análisis, se recogieron opiniones de los avances y se discutieron las decisiones involucradas en cada pieza del proyecto. Se hicieron preguntas directas a los especialistas y en conversaciones abiertas se discutieron los temas de

\section{DESCRIPTION OF THE PROPOSAL}

The PARN is provided in the entire Chilean territory. It aspires to transcend in time and transmit feelings of belonging and equity. For this reason, the shapes, materials, color range and graphics appeal to temporality, local belonging and honesty. Thus, the proposal is solidified through the graphic reinterpretation of different habitats: desert, sea, mountain and forest. For each habitat, its flora and fauna were illustrated. In the case of the sea, images of the Humboldt penguin, the sea lion, the blue whale and the humpback whale were used. In the case of the forest, the pudú, the culpeo fox, the araucaria, the piñón and the copihue were used. The mountain was represented with the puma, the mountain vizcacha and the yareta. Finally, the cactus, the alpaca, the chinchilla and the lizard characterized the desert.

\section{ITERATION PROCESS}

During this stage, the functional and emotional needs were coupled into a single proposal, which mayor relevancia. Por otro lado, se realizaron presentaciones periódicas de los resultados de las encuestas, los avances en la investigación y las decisiones de diseño a los agentes públicos involucrados: Ministerio de Salud, Ministerio de Desarrollo Social y Central Nacional de Abastecimiento del Sistema Nacional de Servicios de Salud.

2. Evaluación: Consideró las primeras impresiones de los usuarios en el testeo de los productos. Quienes diseñamos nos limitamos a observar y a dejar abiertas las opiniones del usuario. Así, se obtuvieron numerosas reacciones y críticas al proyecto, principalmente enfocadas a la comodidad, los materiales y la funcionalidad. Este proceso de evaluación fue realizado tres veces.

3. Satisfacción: Se presentaron los productos finales a los agentes clave del proyecto, quienes aportaron una retroalimentación final considerando factores como comodidad, funcionalidad, color, forma y materiales, entre otros. Se solucionaron detalles formales y, con ello, se

was evaluated through three sub-phases:

1. Group meetings with specialists: The analysis was corroborated, feedback on the advances was collected and decisions involved in each piece of the project were discussed. Direct questions were asked of the specialists and the most relevant topics were discussed in open conversations. On the other hand, regular presentations of the results of the surveys, advances in research and design decisions were made to the public agents involved: Ministry of Health, Ministry of Social Development and National Supply Center from the National Health Service System.

2. Evaluation: The first impressions of the users in the testing of the products were considered. We designers only observed and received the users' opinions. Thus, numerous reactions and criticisms of the project were obtained, mainly focused on comfort, materials and functionality. This evaluation process was carried out three times. 
dio por finalizada la etapa de diseño.

\section{FASE FINAL}

Finalmente, se hizo necesario dejar constancia de todo el proyecto a través de fichas técnicas, las cuales formaron parte de las bases de licitación del proyecto. Además, se hizo necesario recalcar algunos detalles de cada producto, los cuales hacen que éstos destaquen por su calidad, comodidad y funcionalidad. A cada uno de éstos se le asignó un puntaje de evaluación con el objetivo de valorar los estándares de calidad respecto a los proveedores licitantes.

\section{CONCLUSIONES}

En términos globales, equidad y pertenencia fueron las ideas matrices fusionadas por las distintas aristas del proyecto. Desde la función a la emoción, el proyecto buscó resolver las situaciones que conciernen a la llegada de un nuevo miembro a la familia. Las metodologías utilizadas para el levantamiento de información fueron indispensables para descubrir los factores implícitos. Recurrir a medios

3. Satisfaction: The final products were presented to the key agents of the project, who provided their final feedback considering factors such as comfort, functionality, color, shape and materials, amongst others. Formal details were solved and, with that, the design stage was completed.

\section{FINAL PHASE}

Finally, it became necessary to record the entire project on technical sheets, which formed part of the bidding rules of the project. In addition, it was necessary to emphasize some details of each product, which make them stand out for their quality, comfort and functionality. Each one of these received an evaluation score, with the objective of assessing the quality standards with respect to the bidding suppliers.

\section{CONCLUSIONS}

In global terms, equity and belonging were the main ideas that were merged by the different aspects of the project. From function to emotion, informales permitió recabar información explícita y sincera. Tomando en cuenta la amplitud y alcance del proyecto, este proceso resultó fundamental.

El rediseño del ajuar busca aumentar el nivel de uso y satisfacción del PARN, incrementando el sentimiento de orgullo por pertenecer a un contexto geográfico específico. Gracias a su funcionalidad y su estética, el ajuar se transforma en un regalo que logra acoger a la familia en un momento vulnerable.

Este proyecto está creado con el fin de promover la equidad, integrando a todos en un mismo lugar, sin distinción de género, situación económica o social. Finalmente, eso es lo que nos hace ser iguales, es decir, pertenecer.D

the project sought to resolve situations that concern the arrival of a new member of the family. The methodologies used for gathering information were indispensable to discover implicit factors. Resorting to informal means allowed us to collect explicit and sincere information. Taking into account the breadth and scope of the project, this process was fundamental.

The redesign of the baby box aims to increase the level of use and satisfaction of the PARN, increasing the sense of pride in belonging to a specific geographical context. Thanks to its functionality and aesthetics, the baby box becomes a gift that manages to embrace the family during a vulnerable stage.

This project is created with the purpose of promoting equity, integrating everyone in the same place, without distinction of gender, economic status or social situation. In conclusion, that is what makes us equal and that is what allows us to belong.D 


\section{REFERENCIAS / REFERENCES}

CHILE CRECE CONTIGO. (2010). Cuatro años creciendo juntos. Memoria de la instalación del Sistema de Protección Integral a la Infancia. Chile Crece Contigo 2006-2010. Santiago, Chile: MIDEPLAN.

CHILe CRECE contico. (sin año). Acerca de Chile Crece Contigo. Retrieved from Chile Crece Contigo: www. crececontigo.gob.cl/acerca-de-chcc/

DATAVOz . (2014). Estudio de satisfacción usuaria y construcción de línea base. Programa de Apoyo al Recién Nacido (PARN). Informe final. Santiago, Chile.

EMOL. (April 2, 2016). Infografía: Cómo se clasifican los nuevos grupos socioeconómicos en Chile. Retrieved from Emol.com: www.emol.com/noticias/ Economia/2016/04/02/796036/Como-seclasifican-los-grupos-socioeconomicos-en-Chile.html LECANNELIER, F. (2009). Apego e intersubjetividad. Santiago, Chile: Lom.

LECANNELIER, F. (no date). ¿Cué es el apego y cómo podemosfomentarlo con nuestros hijos/as? Retrieved from crececontigo.gob.cl: www.crececontigo.gob. $\mathrm{cl} /$ columna/que-es-el-apego-y-como-podemosfomentarlo-con-nuestros-hijosas

SAAVEDRA NORAMBUENA, C. \& CHILE CRECE CONTICO. (2015). ¿Qué es Chile Crece Contigo? Santiago, Chile: MIDEPLAN. 